\title{
Conversion to thoracotomy of video-assisted thoracoscopic closure of patent ductus arteriosus
}

\author{
Tomasz Stankowski ${ }^{1}$, Sleiman Sebastian Aboul-Hassan ${ }^{2}$, Dirk Fritzsche ${ }^{1}$, Marcin Misterski ${ }^{3}$, Jakub Marczak ${ }^{4}$, \\ Anna Szymańska², Katarzyna Wijatkowska ${ }^{5}$, Cyprian Augustyn ${ }^{5}$, Romuald Cichoń ${ }^{6}$, Bartłomiej Perek ${ }^{3}$ \\ ${ }^{1}$ Department of Cardiac Surgery, Sana Heart Center Cottbus, Cottbus, Germany \\ ${ }^{2}$ Department of Cardiac Surgery, Heart Diseases Center MEDINET, Nowa Sol, Poland \\ ${ }^{3}$ Department of Cardiac Surgery and Transplantology, Poznan University of Medical Sciences, Poznan, Poland \\ ${ }^{4}$ Department of Cardiac Surgery, Wroclaw Medical University, Wroclaw, Poland \\ ${ }^{5}$ Department of Cardiac Surgery, Heart Diseases Center MEDINET, Wroclaw, Poland \\ ${ }^{6}$ Department of Cardiac Surgery, Warsaw Medical University, Warsaw, Poland \\ Kardiochirurgia i Torakochirurgia Polska 2018; 15 (2): 102-106
}

\begin{abstract}
Introduction: Posterolateral thoracotomy was the access of choice in surgical treatment of patent ductus arteriosus (PDA) for many years before the introduction of video-assisted thoracoscopic surgery (VATS). The latter is thought to reduce postoperative pain and improve musculoskeletal system status. However, it carries a potential risk of conversion to thoracotomy. Aim: To evaluate the rate, reasons and outcomes of VATS conversion to thoracotomy in surgical PDA patients.

Material and methods: From 2012 to 2017, 112 children were qualified for VATS closure of symptomatic PDA. Among them, $19(16.9 \%)$ with the median age of 19.4 months required conversion to thoracotomy. The predominant reasons for conversion, early mortality and morbidity as well as late survival were evaluated.

Results: The overall conversion rate was $16.9 \%$ with an evident learning curve as it decreased significantly from more than $20 \%$ at the beginning to approximately $10 \%$ in the last 2 years. The predominant reasons were incomplete PDA closure $(n=6 ; 31.6 \%)$ followed by ductal bleeding after clip application $(n=5 ; 26.3 \%)$ and inadequate visualization $(n=5)$. One child died $48 \mathrm{~h}$ after the surgery due to acute cardiopulmonary failure (mortality 5.9\%). All patients required postoperative chest tube insertion, and two of them developed postoperative pneumothorax. Neither deaths nor severe adverse events were noted throughout the follow-up period.

Conclusions: The rate of VATS PDA closure conversion to standard thoracotomy features a learning curve. Although it must be considered as a serious complication, probably it does not negatively affect either early the mortality rate or long-term survival.
\end{abstract}

Key words: patent ductus arteriosus, video-assisted thoracoscopic surgery, conversion, outcomes.

\section{Streszczenie}

Wstęp: Tylno-boczna torakotomia przez wiele lat była dostępem z wyboru w chirurgicznym zamknięciu przetrwałego przewodu tętniczego (PDA), do czasu wprowadzenia techniki wideotorakoskopowej (VATS). Uważa się, że tę ostatnią cechują mniejsze dolegliwości bólowe i lepiej zachowany stan układu mięśniowo-szkieletowego, ale niesie ona ze sobą ryzyko konieczności konwersji do torakotomii.

Cel: Ocena częstości i przyczyn konwersji VATS do torakotomii i wyników klinicznych takiego leczenia u pacjentów z PDA.

Materiat i metody: W latach 2012-2017 do torakoskopowego leczenia objawowego zakwalifikowano 112 dzieci z PDA. U 19 z nich (16,9\%), mediana wieku 19,4 miesiąca, konieczna była konwersja do torakotomii. W badaniu analizowano główne jej przyczyny oraz wyniki wczesne i odległe.

Wyniki: Częstość konwersji dla całego czasu badania wyniosła 16,9\%. Obserwowano krzywą uczenia, gdyż wskaźnik ten zmniejszył się z ponad 20\% na początku do ok. 10\% w 2 ostatnich latach. Głównymi przyczynami były: niezupełne zamknięcie przewodu ( $n=6 ; 31,6 \%)$, krwawienie z PDA po założeniu klipsa i nieodpowiednia wizualizacja (po $n=5 ; 26,5 \%$ ). Jeden wcześniak zmarł 48 godzin po operacji z powodu ostrej niewydolności sercowo-oddechowej (śmiertelność 5,9\%). Wszystkie dzieci wymagały założenia drenu do klatki piersiowej, a i tak u dwojga z nich stwierdzono odmę. Podczas obserwacji poszpitalnej nie odnotowano zgonów ani istotnych powikłań.

Wnioski: Częstość konwersji VATS do torakotomii podczas zamknięcia PDA cechuje krzywa uczenia. Choć konwersję należy traktować jako poważne powikłanie, to jednak nie wpływa ona niekorzystnie na wczesną śmiertelność lub przeżycie odległe.

Słowa kluczowe: przetrwały przewód tętniczy, chirurgia wideotorakoskopowa, konwersja, wyniki kliniczne.

Address for correspondence: Tomasz Stankowski MD, Department of Cardiac Surgery, SANA Heart Center Cottbus, 3 Leipziger St., 03048 Cottbus, Germany, phone: +49 15226206 370, e-mail: tomekstankowski89@gmail.com

Received: 17.04.2018, accepted: 25.04.2018. 


\section{Introduction}

Ductus arteriosus as a fetal blood vessel between the proximal descending aorta and the roof of the main pulmonary artery near the origin of the left branch normally closes within a week after birth [1, 2]. In some infants, particularly preterm born before the $28^{\text {th }}$ week of pregnancy, the ductus arteriosus remains patent (PDA) longer and treatment is mandatory [3]. This common congenital disorder is routinely managed with cyclooxygenase inhibitors. However, if pharmacological treatment fails or is considered to be contraindicated, interventional procedures are performed [4]. Among them a method of choice is percutaneous closure of PDA. Unfortunately this minimally invasive technique is not applicable in all children. Thus even currently surgical treatment is still an important therapeutic option in management with symptomatic PDA patients. A posterolateral thoracotomy has been the standard approach for many years [4]. In the 1990s Laborde et al. developed the video-assisted thoracoscopic surgical (VATS) method to occlude PDA [5]. Although markedly more difficult and requiring surgical skills, this minimally invasive surgical technique was shown to provide faster postoperative recovery, shorten in-hospital stay, decreased chest wall deformations and a reduced rate of other surgical complications [6-10]. Despite the obvious advantages of thoracoscopy, this access is associated with potential risk of conversion to traditional thoracotomy that may impact unfavorably on early and late outcomes.

\section{Aim}

Considering the above, the purpose of this study was to evaluate the rate, predominant reasons and late outcomes of children who during primary surgery for PDA required emergent conversion of VATS to posterolateral thoracotomy.

\section{Material and methods \\ Patients}

In the years 2012 to 2017, 112 children, including preterm infants, underwent PDA closure using the VATS technique. In 93 cases, thoracoscopic occlusion was completed successfully whereas in 19 children emergent conversion from VATS to posterolateral thoracotomy was necessary (Fig. 1). The detailed preoperative demographic and clinical data are outlined in Table I. The institutional review board waived individual patient approval due to the retrospective nature of this study.

\section{Operation}

All VATS procedures were performed under general anesthesia. After endotracheal intubation and catheter insertion the patients were then placed in the right lateral decubitus position. It must be stated that in the first half-year of 2012 only selected PDA patients underwent VATS, whereas from June 2012 all operations for PDA were done with the minimally invasive technique. The VATS procedures were carried out by means of three ports: one for the video- camera insertion in the fourth or fifth intercostal space in the anterior axillary line and the other two for surgical instruments in the third and sixth spaces in the posterior axillary line. The cavity was insufflated with carbon dioxide under pressure of 5 to $7 \mathrm{~mm} \mathrm{Hg}$. In the case of emergent conversion to thoracotomy, the first incision usually in the fourth intercostal space was extended followed by retractor placement. In patients with pleural adhesions, first they had to be dissected free then the PDA was localized and occluded by clips. Before chest closure, a tube was placed in all patients. Doppler transthoracic echocardiography was done in the operating room to confirm complete closure of the duct.

\section{Early and late post-operative period}

After surgery, patients were transferred to the Pediatric Cardiothoracic Intensive Care Unit (ICU). Chest drains were usually kept at least for $12 \mathrm{~h}$ following surgery. In-hospital mortality and morbidity were analyzed. After discharge all children underwent systematic clinical follow-up in the outpatient clinic.

\section{Data presentation and statistical analysis}

Continuous variables are expressed as the means \pm standard deviations if they satisfied criteria of normal distribution in the Shapiro-Wilk $W$ test or as the medians with ranges (minimum; maximum) for the others. The former were compared with unpaired Student's $t$ test whereas the latter data were compared with the Mann-Whitney $U$ test. Categorical data are presented as numbers $(n)$ and percentages (\%). A $p$-value $<0.05$ was considered statistically significant. All statistical analyses were performed using Statistica 10.0 for Windows software (StatSoft, Inc., Tulsa, OK, USA).

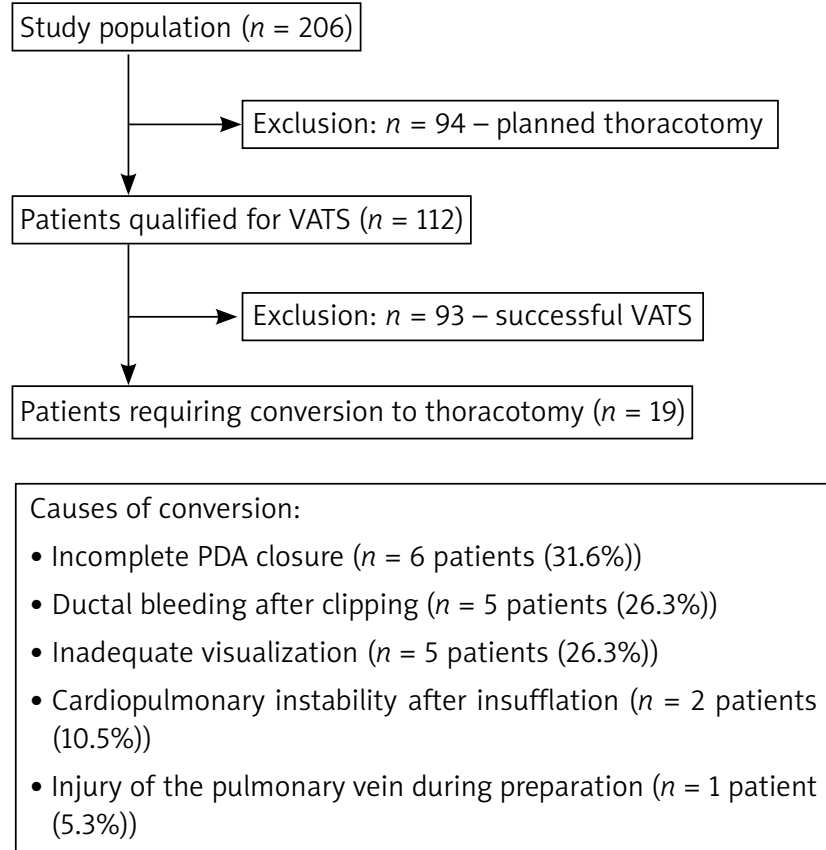

Fig. 1. Study population 
Table I. Demographic and selected baseline clinical data

\begin{tabular}{lccc} 
Parameter & Converted patients $(n=19)$ & Successful VATS patients $(n=93)$ & P-value \\
Age [months] & $2.1(0.7-117.9)$ & $4.5(0.3-192.0)$ & 0.982 \\
\hline Gender (female/male) & $14(73.7) / 5(26.3)$ & $53(57.0) / 40(43.0)$ & 0.161 \\
\hline Preterm infants & $7(36.8 \%)$ & $44(47.3 \%)$ & 0.410 \\
\hline Weight at delivery $[\mathrm{kg}]$ & $2.52(0.48-3.82)$ & $2.50(0.45-5.10)$ & 0.868 \\
\hline Weight at surgery [kg] & $4.2(0.8-36.0)$ & $6.6(0.7-64.0)$ & 0.755 \\
\hline PDA diameter [mm] & $5.4 \pm 1.9$ & $3.7 \pm 1.1$ & $0.001^{*}$ \\
\hline Comorbidities: & $11(57.8)$ & $43(46.2)$ & 0.354 \\
\hline Heart failure & $8(41.1)$ & $18(19.4)$ & $0.032^{*}$ \\
\hline Respiratory failure & $9(47.4)$ & $40(43.0)$ & 0.727 \\
\hline Pulmonary hypertension & $2(10.5)$ & $3(3.2)$ & 0.160 \\
\hline Bronchopulmonary dysplasia & $3(15.8)$ & $9(9.7)$ & 0.433 \\
\hline Perinatal asphyxia & $3(15.8)$ & $20(21.5)$ & 0.574 \\
\hline Anemia of prematurity & $4(21.1)$ & $27(29.3)$ & 0.478 \\
\hline Intraventricular hemorrhage & $4(21.1)$ & $16(17.2)$ & 0.690 \\
\hline
\end{tabular}

Continuous variables are presented as mean \pm SD or median with range (minimum; maximum) whereas categorical variables are presented as number ( $\mathrm{n}$ ) with percentage (\%); *difference of statistical significance; converted vs. successful VATS patients; PDA - patent ductus arteriosus.



Fig. 2. Number of all VATS and converted patients in consecutive years of study

\section{Results}

\section{Preoperative characteristics}

Comparison of preoperative demographic and clinical data revealed that patients who required conversion more often presented symptoms of heart failure and had a larger PDA diameter (calculated in echocardiography). More details are listed in Table I.

\section{Rate and reasons for conversion}

Our experience with VATS PDA closure revealed a learning curve. It was confirmed by the observed rate of VATS conversion to posterolateral thoracotomy. This rate was generally higher in the first years of VATS application and it decreased to approximately $10 \%$ in the last 2 years (Fig. 2). Moreover, during the last 25 procedures emergent thoracotomy had to be carried out only in 2 (8\%) children.
The most common cause of conversion was incomplete PDA closure, followed by ductal bleeding after clipping or inadequate visualization. The others are shown in Figure 1.

\section{In-hospital period}

There was no intraoperative mortality either in converted or successful VATS children. In the early postoperative period 2 patients (one in each group) died. One converted preterm infant died 2 days after the surgery due to cardiopulmonary failure (mortality rate $5.3 \%$ ).

Drainage insertion was necessary in all converted patients and the median (minimal-maximal) postoperative blood loss was $15(2 ; 200) \mathrm{ml}$. The chest tube was removed after $28.7 \pm 12.4 \mathrm{~h}$.

Due to conversion, not only operation time (defined as skin incision to skin closure) but also hospitalization in the postoperative ICU increased significantly, from 45 (15-125) $\min$ to $90(45-215) \min (p<0.001)$ and from $2(1-5)$ to $3(2-6)$ days $(p<0.001)$, respectively. Eight patients were discharged home after an average of $4.6 \pm 0.7$ days. Ten children (10 out of 18 who survived hospitalization in postoperative ICU; 55.5\%) were transferred to a Neonatal Intensive Care Unit (NICU) compared to 37 (39.8\%) after successful VATS PDA closure ( $p=$ NS). The median NICU stay length of converted patients was 28 days (range: 3-94).

Interestingly, conversion had only a slight, not statistically significant impact on the percentage of patients who required blood product transfusion (25 (26.9\%) vs. 9 (47.4\%); $p=0.077)$.

Postoperative pneumothorax occurred in two patients, but only one of them required chest tube insertion. No cases of chylothorax, excessive bleeding, atelectasis, wound infection or recurrent laryngeal dysfunction were observed. 


\section{Late outcomes}

All patients completed follow-up that lasted for 5 to 70 months. A last follow-up echocardiographic examination confirmed successful PDA closure in all cases. Although 2 patients presented low-grade scoliosis, additional treatment was not indicated. No cardiac deaths or other adverse events were recorded the throughout follow-up period.

\section{Discussion}

The minimally invasive approach for PDA closure by means of VATS has a lot of advantages, but this technically demanding approach is associated with the risk of emergent conversion to traditional posterolateral thoracotomy [11]. This rate has been described in the literature within a wide range from almost minimal to approximately $18 \%$ $[12,13]$. Not uncommonly high volume VATS centers presented better results. For example, Nezafati in a group of 2000 and Villa in a group of more than 700 children reported a conversion rate at the level below $1 \%$, whereas Jacobs et al. reported $13.3 \%$ in a study that involved only 45 cases [14-16]. Although our rate is within the reported range, it seems to be relatively high. It must be stressed that our study involved all patients treated with this method, even the first cases. Moreover, we proved the existence of a learning curve for VATS to close PDA that is typical for all minimally invasive surgical interventions. Currently, having experience with more than one hundred cases, it is markedly below $10 \%$.

Although conversion from VATS to posterolateral thoracotomy is usually considered a serious adverse event, its causes may affect early and late outcomes. If the reason for conversion is inadequate PDA obstruction or suboptimal visualization, outcomes should not be compromised, whereas ductal wall rupture, bleeding or hemodynamic instability, all requiring emergent decision, may be associated with a worse prognosis. In our group the predominant cause of conversion $(n=6)$ was residual shunt detected in the routine postoperative echocardiography done in the operating room. This complication was also described previously [11, 15]. Adequate visualization is crucial for successful surgery, particularly in minimally invasive procedures. In some patients, surgeons can expect technical problems to achieve optimal conditions but in others it is almost impossible. In four of our 5 children converted due to improper visualization, the conversion was deemed necessary because of extensive pleural adhesions. Among them two had a history of bronchopulmonary dysplasia. In the earlier reports, conversions were necessary predominantly due to aforementioned reasons; thus in-hospital and late outcomes of converted patients were not affected negatively by a need for conversion. Our study supported these previous findings.

During VATS procedures only one lung (the right one) is ventilated and additionally active compression of the other one with carbon dioxide insufflation under pressure of 5-7 $\mathrm{mm} \mathrm{Hg}$ is applied. Non-physiological high pressure in the thorax may lead to a decrease in systemic and pulmonary venous return, then a drop in the cardiac index and mean arterial pressure which eventually cause cardiopulmonary failure [17]. In our group, both converted unstable patients were preterm infants (810 and $1320 \mathrm{~g}$ ).

A particularly challenging group of patients is that of preterm infants in whom complications of prematurity could have a significant impact on the surgical outcome [18]. They present high perioperative mortality regardless of the therapeutic tool applied to close the PDA, even if they do not need conversion to thoracotomy [19]. They are more prone to be hemodynamically unstable during VATS procedures, as was also noted in our observation. In our study, 7 preterm infants were converted from thoracoscopy to the conventional approach. One of them, born as a very low birth weight infant before the $30^{\text {th }}$ week, died $48 \mathrm{~h}$ after the surgery due to acute cardiopulmonary dysfunction. The conversion was performed because of incomplete PDA closure. This patient presented a preoperatively critical state with many comorbidities such as heart failure, respiratory failure, fetal infection, anemia of prematurity and intraventricular hemorrhage. We are certain that the death was associated with prematurity rather than conversion during VATS itself.

We reconfirmed that conversion is usually not related to serious complications, either organ or surgical. The surgical incision in converted children is longer than in the case of not only a successful VATS procedure but also the elective thoracotomy approach. Fortunately, it did not affect wound healing. No surgical site infections were noted in our group, which was consistent with other reports. It was also previously suggested that thoracotomy, particularly posterolateral, might be associated with higher prevalence of postoperative scoliosis (even up to 50\%) [6, 20]. In our group such chest asymmetry was seen in two patients but it was relatively mild and no additional procedures had to be done.

\section{Conclusions}

The rate of VATS PDA closure conversion to standard thoracotomy features a learning curve. Although it must be considered as a serious complication, probably it does not negatively affect either the early mortality rate or longterm survival.

\section{Disclosure}

Authors report no conflict of interest.

\section{References}

1. Schneider DJ, Moore JW. Patent ductus arteriosus. Circulation 2006; 114: 1873-1882.

2. Gournay V. The ductus arteriosus: physiology, regulation, and functional and congenital anomalies. Arch Cardiovasc Dis 2011; 104: 578-585.

3. Bose CL, Laughan MM. Patent ductus arteriosus: lack of evidence for common treatments. Arch Dis Child Fetal Neonatal Ed 2007; 92: 498-502.

4. Wang K, Pan X, Tang Q, Pang Y. Catheterization therapy vs surgical closure in pediatric patients with patent ductus arteriosus: a meta-analysis. Clin Cardiol 2014; 37: 188-194.

5. Laborde F, Noirhomme P, Karam J, Batisse A, Bourel P, Saint Maurice O. A new video-assisted thoracoscopic surgical technique for interruption of patient 
ductus arteriosus in infants and children. J Thorac Cardiovasc Surg 1993; 105: 278-280.

6. Lawal TA, Gosemann JH, Kuebler JF, Glüer S, Ure BM. Thoracoscopy versus thoracotomy improves midterm musculoskeletal status and cosmesis in infants and children. Ann Thorac Surg 2009; 87: 224-228.

7. Stankowski T, Aboul-Hassan SS, Marczak J, Cichon R. Is thoracoscopic patent ductus arteriosus closure superior to conventional surgery? Interact Cardiovasc Thorac Surg 2015; 21: 532-538.

8. Stankowski T, Aboul-Hassan SS, Marczak J, Szymańska A, Augustyn C, Cichoń R. Minimally invasive thoracoscopic closure versus thoracotomy in children with patent ductus arteriosus. J Surg Res 2017; 208: 1-9.

9. Burke RP, Jacobs JP, Cheng W, Trento A, Fontana GP. Video-assisted thoracoscopic surgery for patent ductus arteriosus in low birth weight neonates and infants. Pediatrics 1999; 104: 227-230.

10. Gentilino V, Macchini F, Morandi A, Leva E. Evidence for thoracoscopic ligation of patent ductus arteriosus. Eur J Pediatr Surg 2016; 26: 219-220.

11. Esfahanizadeh J, Meybodi NA, Shamloo AS, Shakiba AH, Hooshiar A, Tashnizi MA, Jarahi L, Moeinipour AA, Mottahedi B. Video-assisted thoracoscopic versus open surgery for persistent ductus arteriosus: report of 10 years' ex perience. Life Sci J 2013; 10: 1068-1072.

12. Kennedy AP Jr, Snyder CL, Ashcraft KW, Manning PB. Comparison of musclesparing thoracotomy and thoracoscopic ligation for the treatment of patent ductus arteriosus. J Pediatr Surg 1998; 33: 259-261.

13. Liem NT, Tung CV, Van Linh N, Tuan TM, Quang le H, Tu TT. Outcomes of thoracoscopic clipping versus transcatheter occlusion of patent ductus arteriosus: randomized clinical trial. J Pediatr Surg 2014; 49: 363-366.
14. Nezafati MH, Soltani G, Mottaghi H, Horri M, Nezafati P. Video-assisted thoracoscopic patent ductus arteriosus closure in 2,000 patients. Asian Cardiovasc Thorac Ann 2011; 19: 393-398.

15. Villa E, Vanden Eynden F, Le Bret E, Folliguet T, Laborde F. Paediatric videoassisted thoracoscopic clipping of patent ductus arteriosus: experience in more than 700 cases. Eur J Cardiothorac Surg 2004; 25: 387-393.

16. Jacobs JP, Giroud JM, Quintessenza JA, Morell VO, Botero LM, van Gelder HM, Badhwar V, Burke RP. The modern approach to patent ductus arteriosus treatment: complementary roles of video-assisted thoracoscopic surgery and interventional cardiology coil occlusion. Ann Thorac Surg 2003; 76: 1421-1427.

17. Shah R, Reddy AS, Dhende NP. Video assisted thoracic surgery in children. J Minim Access Surg 2007; 3: 161-167.

18. Hines MH, Raines KH, Payne RM, Covitz W, Cnota JF, Smith TE, O'Brien JJ, Ririe DG. Video-assisted ductal ligation in premature infants. Ann Thorac Surg 2003; 76: 1417-1420.

19. Stankowski T, Aboulhassan SS, Fritzsche D, Misterski M, Marczak J, Szymańska A, Szarpak L, Augustyn C, Cichoń R, Perek B. Surgical closure of patent ductus arteriosus in extremely low birth weight infants less than 750 grams. Kardiol Pol 2018; 76: 750-754.

20. Chen H, Weng G, Chen Z, Wang H, Xie Q, Bao J, Xiao R. Comparison of posterolateral thoracotomy and video-assisted thoracoscopic clipping for the treat ment of patent ductus arteriosus in neonates and infants. Pediatr Cardiol 2011; 32: 386-390. 